\title{
The Concept of Justice In Greek Philosophy (Plato and Aristotle)
}

\author{
Afifeh Hamedi \\ Dept Of Philosophy of Education, Bushehr branch, Islamic Azad University, Bushehr, Iran \\ Email: hamedi.a2010@gmail.com
}

\section{Doi:10.5901/mjss.2014.v5n27p1163}

\begin{abstract}
The Greeks looked upon justice as virtue in action and therefore a virtue. The Greek conception of justice was the virtue of soul and injustice its vice. To both Plato and Aristotle justice meant goodness as well as willingness to obey laws. It connoted correspondence of rights and duties. Justice was the ideal of perfection in human relationships. And the spirit which animated men in the proper discharge of their duties. The promotion of balance and harmony in thought and action was pre-eminently social in character. Nature was the source of law and the duty of the state was ordinarily considered to be the application rather than the creation of the law. Aristotle, and Plato's justice, in fact both are complementary to each other, the aim of both philosophers is to find of a principle of capacity through which, unity, harmony, virtue and happiness can be established in the society. But in spite of this common agreement they differ in many fundamental respects from each other. This study will examine plato and Aristotle theory of justice and then a comparison between them.
\end{abstract}

Keywords: Plato, Aristotle, Justice, harmony.

\section{Introduction}

Justice has been one of the important issues in the history of philosophy. The Greek conception of justice was the virtue of the soul and action. To both Plato and Aristotle, justice meant goodness as well as willingness to obey laws. It connoted correspondence of rights and duties. Justice was the ideal of perfection in human relationships. To Plato, "justice was one of the highest of virtues .(bhandari,2002) Justice to the Greeks, was the spirit which animated men in the proper discharge of their duties. The promotion of balance and harmony in thought and action was pre-eminently social in character.

"The Greeks were devoted to their laws partly because of the belief in their superhuman origin and partly because the general principles embodying the law were believed to be perfect and permanent and not subject to change at the will of the people. Nature was the source of law and the duty of the state was ordinarily considered to be the application rather than the creation of the law. Law, to the Greeks, was moral because it was natural and, therefore, it constituted the cement of the city-state. Law was the same for all and, therefore, in a way, it meant freedom. Obedience to laws was an essential element in the Hellenic conception of liberty.To the Greeks, "the city-state was both a church as well as a political institution, and its end was to promote among its citizens goodness and justice, the latter representing an ideal perfection in human relationships.(Bhandari,2002) This part deals with the theories of Plato and Aristotle as follows:

\section{Plato's Theory of Justice}

Plato of Athens born of a noble family, about 427, was a pupil of Socrates and the oldest Greek Philosopher. The chief source of inspiration for Plato was Socrates. One of the most important questions of Socrates, was about the nature of justice. After Socrates, "Plato, also regarded justice as the true principle of social life. And he has named his most important work. Republic, as a discussion on justice. Dr. Barker, therefore, has pointed out that "Justice is the hinge of his thought. (Barker,1952) In his contemporary world Plato saw states everywhere cities so divided that their citizens stood "in the state and posture of gladiators" against one another. He saw unrighteousness rampant and injustice enthroned. He saw ignorance supreme and parading up and down in the guise of knowledge .(Wayper,1954) Thinking mainly of the Athenian democracy in which he lived and at the hands of which Socrates had been killed, he found the contemporary politics of his day dominated by two things: One was the ignorance and the other was a political selfishness which divided every city into two hostile cities. "To create efficiency in the place of amateur incompetence to replace selfishness and civil discord by harmony ,these are therefore, his aims, and specialization and unification are, therefore, his watchwords. To these two aims ,the political teaching of the Republic is addressed".(Barker,1952) The far-seeing eyes of the 
philosopher could foresee that any plan for perfecting the city-state will not be complete unless it meets incompetence and factionalism, which were the two fundamental political evils of the day.(Sabin,1949) Plato found in justice the remedy for curing these evils.

The main argument of the Republic is a sustained search after the location and the nature of justice. Plato follows this search with the help of the method of elimination. He discovers and locates justice with the help of his ideal state. He reviews the various theories of justice representing various stages in the development of the conceptions of justice and morality, and finally gives his own. According to Plato, justice is that in individual life, different parts of soul are placed in their proper place, and in social life, each individual and each class is placed in its proper place. Plato believed that the human nature is made from, wisdom, courage, and appetite. And each class according to prevalence of one of this capacities, places in the social and moral hierarchy. Plato's justice does not state a conception of rights but of duties through it is identical with true liberty. Justice is a quality - an indispensable quality of moral life. It is condition of the individual and of the state and the ideal state is the visible embodiment of justice. The state is the reality of which justice is the idea.

To Plate, "Justice, like the ideal state, therefore, it demands division of society into three classes representing the elements of reason, spirit and appetite, one man, one work, on the basis of functional specialization, a state-regulated scheme of education, the rule of philosopher-rulers and their emancipation from domestic and economic worries by a system of communism, and emancipation of women and their equality with men. Plato's concept of justice is based on the submergence of the individual in the society. It refers to the whole duty of man and not merely his legal duties".(Bhandari,2002) Plato in his theory of state mentions that there are five types of political organizations: aristocracy, the rule of the best; timocracy, in which the rulers are motivated by honour; oligarchy, in which the rulers seek wealth; democracy, the rule of the masses; tyranny, the rule of one man advancing solely his own selfish interests.

In the Republic Plato gives an outline of what he regards as the Ideal state. It is a form of intellectual aristocracy. The state is the individual writ large. On the analogy of the tripartite division of the soul, society is stratified into three classes, the rulers, the auxiliary, and the artisans, each class having its own specific virtue: the rulers wisdom, the auxiliary valour, and the artisans self-restraint and willing obedience. To keep people contented in their respectie classes the state would have to propagate "a royal lie" that God has created human beings of three kinds: the best are made of gold, the second are made of silver, and the common herd of brass or iron, the first fit to be guardians, the second warriors, and the rest manual workers.(Sharif,2001) "These three classes, working in proper correlation, will insure the maximum of well-being throughout the state. Every member of the community must be assigned to the class for which he proves himself best fitted. Thus, a perfect harmony and unity will characterize both the state and every person in it".(Dunning,1966) Plato says in this field:

"Well then, tell me, I said, whether I am right or not, you remember the original principle which we were always laying down at the foundation of the state, that one man should practice one thing only, the thing to which his nature was best adapted; now justice is this principle or a part of it. Yes, we often said that one man should do one thing only."(Plato)

In his theory of Ethics, Plato held that the soul is in essence rational and immortal. The world of true beings, the world of ideas, is the source of all its goodness. The body is material and is the ground of all-evil. It is only a temporary prison house. Release from the body and contemplation of the beautiful ream of ideas, is the ultimate goal of life. The embodied soul is wise if reason rules all its impulses. It is brave if its spirited part aids and obeys the rational part, temperate, if both spirit and appetite obey the dictates of reason, and just. If all the three parts perform their respective functions in unison. The idea of this life is achieved when a man is wise, brave, temperate, and just. The highest good of life is the harmony of the soul which is attained by the exercise of all the four virtues, wisdom, courage, temperance, and justice, under the guidance of reason. The greatest happiness attends the life that achieves the highest good and contemplates the highest ideas.(Sharif,2001)

For Plato, justice is the fundamental virtue, mother of the virtues belonging to each of the three souls. For the intelligence it consists in the correctness of thought; for the will, in courage for the sensibility, in temperance. Wisdom is the justice of the mind; courage, the justice of the heart; temperance, the justice of the senses. Piety is justice in our relation with the Deity; it is synonymous with justice in general. ${ }^{17}$ Man must be educated in order to reach justice and through it to become like God. Justice is realized only in the collective man or in the state. In order that the collective man or the state may form a real unity or an individual on the large scale, particular interests must be merged in the general interest, the family must be absorbed in the state, the individual must cease to be a proprietor. Henceforth, the children belong to the state only, which forms one large family. The state is the father of the children; the state also educates them.(Weber,200) 
Justice, to Plato, has a moral rather than legal content. It has its individual and social aspects. Justice is a principle of non-interference, which keeps within proper bounds the various classes of society, various individuals of each class and various elements in an individual's soul. It is a principle of functional specialization, which moves everyone to make a specialized contribution to society. Specialization leads to efficiency. Justice is architectonic and keeps other virtues in harmonious relationship with each other. It permeates and integrates the other virtues of wisdom, courage and selfcontrol and keeps them within proper bounds. As such, justice is the bond that holds the society together.(Bhandari,2002)

\section{Aristotle's Theory of Justice}

Aristotle was born at Stagira in Thrace in 384 B.C. and he died in 322. He was the greatest of Plato's disciples and he took his inspiration on many things from his celebrated teacher.Aristotle believed, like his master, Plato, that justice is the very essence of the state, and that no polity can endure for a long time unless it is founded on a right scheme of justice. It is with this consideration in view that Aristotle proceeds to set forth his theory of justice. The theory, however, was not developed by him in isolation. The Republic of Plato serves as a great guide Generally, Aristotle believes that every things have especial aim and man's especial aim is to reach the real happiness. He sat the concept of human happiness basis of his discussion, and explains the concept of justice on the basis of individual life- He says in this field:

Justice is relative to persons, and a justice distribution is one in which the relative values of the things given correspond to those of the persons receiving.(Aristotle,1980) According to Aristotle, justice in individual is the harmony in the human soul, and in the society is equality and proportion in the enjoyment of values. In the Aristotle's political philosophy, essential criterion of justice is treating equals equally and un-equals unequally but in proportion to their relevant differences. He says in his politics: "In all sciences and arts the end is a good, and especially and above all in the highest of all - this is the political science of which the good is justice. In other words, the common interest. All men think justice to be a sort of equality; and to a certain extent they agree in the philosophical distinctions which have been laid down by us about Ethics. For they admit that justice is a thing having relation to persons, and that equals ought to have equality. However there still remains a question - equality or inequality of what? Here is a difficulty which the political philosopher has to resolve".(Aristotle,1953) Justice, to Aristotle as to Plato, is virtue in action. Justice means that every member of a community should fulfill his moral obligation towards the fellow-members of his community.

Justice in the political sense, has two divisions : 1 . distributive justice and 2. corrective justice. Corrective justice is concerned with voluntary commercial transactions like sale, hire furnishing of security, etc., and other things like aggression on property and life, honour and freedom."(Bhandari) Distributive justice consist in proper allocation to each person according to his worth or deserts. This type of justice relates primarily but not exclusively to political privileges. From this point of view, each type of political organization has its own standard of worth and, therefore, of distributive justice. In a democracy, the standard of worth is free birth; in an oligarchy it is riches, in aristocracy of birth it is descent while in true aristocracy it is virtue. "Distributive justice assigns to every man his due according to his contributions to the society. It minimizes strife and confusion by countering inequality of the equals or the equality of the un-equals. Aristotelian distributive justice is, thus, the other name of proportionate equality i.e., a man's rights, duties and rewards should correspond to his merit and social contribution."(Ibid) In the politics of Aristotle, the first natural community for him is the family, which, when complete, consists of father, wife, children, and slaves. The family is based on two relations: the relation between man and woman and that between master and slave, both of which are considered to be natural. To all members of the family the father is an absolute ruler, but he should rule the slaves with mildness, the wife as a free member of the community, and children by right of affection and seniority.(Aristotle,1953) The most comprehensive human society is the state. The aim of the state is to produce good citizens, individuals living a virtuous and happy life. As the highest virtues are intellectual, it is the duty of the state not to create warriors, but men capable of making the right use of peace, which is conducive to intellectual activity. The state should be strong enough to protect itself. The state should be wage no wars except in self-defence or to subjugate natural slaves, i.e., inferior people. The Greeks combine courage with culture and are therefore, superior people; and the superior people are alone justified in extending their rule over those who are inferior.(Sharif)

The treatment given to citizen should be determined by the differences of capability, property, birth, and freedom. Equals should be treated as equals and un equals as un equals. Although the individual citizen is prior to the state in point of time, the state is prior to the individual in significance, for the whole is prior to its parts. As man is a social animal, the natural aim of the individual is to live in society. The rational aim of society is the happiness of man. So in a rational society ,the interest of the individual and the state are harmonized.To Aristotle, the worth of the individual citizens depends on the kinds of government under which they are brought up. A government is good when it aims at the good of the whole community, bad when it cares only for itself. "there are three forms of good government (monarchy, aristocracy, 
and polity), and three forms of bad government (tyranny, oligarchy, and democracy), according as the rule is of one man, of a few, or of many. The best form of government is a monarchy in which the ruler is a man of intellectual eminence and moral worth. Next best is aristocracy in which there are a few persons possessed of such qualities". There is therefore a difference between the rule of the best (aristocracy) and of the richest (oligarchy), since the best are likely to have only moderate fortunes. There is also a difference between democracy and polity, in addition to the ethical difference in the government, for what Aristotle calls polity retains some oligarchic elements. But between monarchy and tyranny the only difference is ethical. Aristotle believes that monarchy is better than polity. But the corruption of the best is worst; therefore tyranny is worse than oligarchy, and oligarchy than democracy. In this way Aristotle arrives at a qualified defence of democracy; for most actual governments are bad, and therefore, among actual government, democracies tend to be the best.Democracy, Aristotle says, arises from the belief that men who are equally free should be equal in all respects; oligarchy, from the fact that men who are superior in some respect claim too much. Both have a kind of justice, but not the best kind.(Russel,1961) In the theory of mortality Aristotle raises the question of the good for man- the good which is the end of all human ends.(Aristotle)

According to Aristotle, the ultimate end of man is happiness which is an activity of the soul. Aristotle says that Plato was right in dividing the soul into two parts, one rational, and the other irrational. The irrational part itself he divides into the vegetative and the appetitive.(Russel,1961) From this definition of happiness it follows that it is not the same thing as pleasure. Pleasure is only beauty is the accompaniment of the perfect physical development of youth. The highest pleasure attends the highest happiness. While in all its degrees is good, pleasure may be good or bad according as it accompanies good or bad activities.

The ethical goal of happiness cannot be attained without some non-ethical prerequisites, such as the proper discharge of mental and bodily functions and the satisfaction of economic needs. Human happiness manifests itself in two ways: first in the habitual subordination of the animal side of man's nature, his appetites, desires, and passions, to rational rule; secondly, in the exercise of reason in the search for knowledge and contemplation of truth. In the former case, happiness expresses itself in moral virtues (courage, temperance, liberality, magnanimity, love of honour, mildness, truthfulness, friendship, and the highest of them all, justice). In the latter case, it manifests itself in intellectual virtues which are of two types: 1. those of theoretical reason which we use in our inquiry in the nature of what is necessary and in the intuitive apprehension of truth (science and reason), and 2. those of practical reason by which we exercise deliberation in such matters as are possible for us to change (art and practical wisdom). ${ }^{32}$ Aristotle is a pronounced supporter of the freedom of will. He criticized Socrates because the latter's theory of virtue practically amounts to a denial of freedom. According to Socrates, whoever thinks right must necessarily do right. But this is equivalent to denying a man's power to choose evil. And if he cannot choose evil, he cannot choose good. Aristotle believed, on the contrary, that, "man has the choice of good and evil. The doctrine of Socrates makes all actions involuntary. But in Aristotle's idea only actions performed under forcible compulsion are involuntary. Aristotle did not, however, consider the special difficulties in the theory of free will which in modern times have made it one of the most theories of all philosophical problems".(Stace,1962)

\section{Conclusion}

Aristotle's and Plato's justice, in fact, both are complementary to each other, but they differ in many fundamental respects from each other. For example, Aristotelian justice lays emphasis on a system of rights, while Platonic justice attaches more importance to duties. The Aristotelian justice is based, as it were, on the principle that "everyone should have his own". The Platonic justice, on the contrary, is based on the principle of "every one should do his own". The former, therefore, is a system of rights but the latter is a system of duties. Also Aristotelian justice establishes equality between different members of the state, while the Platonic justice establishes a hierarchy of classes. According to this justice, citizens are divided into three classes, each of which performs a particular set of functions. Every citizen is bound to do his duties for which he is called as an organ of the state. On the other hand, the Aristotelian justice is based on a classification of complete and particular justice. Plato does not attempt any such classification. His justice rests on three different elements of the human soul-reason, spirit and appetite. However in spite of this difference, there is a ground of common agreement also. The aim of both the philosophers is to find out a principle of capacity through which unity, harmony, virtue and happiness can be established in the society. The purpose of both is to give every citizen his due in accordance with his capacity or nature. Thus, justice in the case of both can be regarded as distributive in character. In both cases, justice is ultimately functional and teleological, and is not merely a legal, but also a moral principle. 


\section{References}

Aristotle (1953) Politics, Translated by Jowett, London, Reprinted Oxford At the Clarendon Press, pp.26- 125.

Aristotle,(1980) The Nicomachean Ethics, Translated by Commentaries and Glossary by Hippocrats G. Apostle, D. Redial Publishing, London, Book E, 5.

Barker, E.,(1952) Greek Political Theory- Plato and His Predecessors, London, 4th edition, pp.149- 153.

Bhandari, D.R.,(2002) Reprint History of European Political Philosophy, Bangalore, Bappco, the Bangalore Press, pp. 5-54.

Dunning, W.A.(1966) Political Theories-Ancient and Medieval, Allahabad, Copyright, Vol. 1, pp. 28-29.

Plato's Republic, Jowett's Translation, The Modern Library, New York, pp. 147-148.

Russell, Bertrand,(1961) History of Western Philosophy, pp.185-201.

Sabin, G.H.(1949) A History of Political Theory. $3^{\text {rd }}$ edition, p. 52.

Sharif, M.M.,(2001) History of Muslim Philosophy, Delhi, Adam Publishers, Vol. 1, pp. 98-104.

Stace, W.T.,(1962) A Critical History of Greek Philosophy, London, Macmillan, p. 320.

Wayper, C.L.(1954), Political Thought, England, $1^{\text {st }}$ edition, p. 16.

Weber, Alferd,(2000) History of Philosophy, Indian, Translated by Frank. Thilly, India, Surjeet Publication, $2^{\text {nd }}$ Reprint, p. 73. 